\title{
PRÁTICAS DE ESCRITAS EXTRAESCOLARES RECONFIGURANDO AS PRÁTICAS ESCOLARES*
}

\author{
EXTRACURRICULAR WRITTEN PRACTICES RECONFIGURING SCHOOL PRACTICES
}

Paulo César Gonçalves

Edilaine Buin

Universidade Federal da Grande Dourados - UFGD

\section{RESUMO}

Este artigo expõe o desenvolvimento de uma proposta de escrita em um $2^{\circ}$ ano do Ensino Médio de uma escola rural do Distrito Santa Terezinha, em Itaporã-MS e uma parte de seus resultados, a fim de promover uma reflexão em torno de novas possibilidades de trabalhos que contribuam para eliminar o abismo entre práticas de escritas escolares e as extraescolares e suas relações sócio históricas. Partimos do pressuposto que a escrita é heterogeneamente constituída, que os fatos linguísticos não se separam das práticas sociais (Corrêa, 2004). A proposta constituía da produção de um Jornal Virtual no Facebook, desenvolvido durante as aulas de Língua Portuguesa. As análises das produções de notícias e reportagens, mais os comentários possibilitados pela plataforma digital, possibilitam mostrar linguisticamente que não há uma fronteira rígida entre práticas de escrita da cultura grafocêntrica e aquelas da cultura digital, como supõem muitos educadores. Além disso, mostram que as redes sociais na escola podem funcionar como colaboradoras de um ensino de escrita mais eficiente e significativo para todos os envolvidos.

Palavras-chave: ensino de língua portuguesa, letramentos, letramento digital, facebook

\begin{abstract}
This paper exposes the development of a written proposal in a 2nd year high school students in a rural school district Santa Terezinha in Itaporã-MS and a part of its results, to promote a reflection on new possibilities for work that contribute to close the gap between school written practices and extracurricular and their socio historical relations. We begin from the assumption that the writing is heterogeneously formed the linguistic facts do not separate the social practices (Corrêa, 2004). The proposal constituted the production of a Virtual Journal on Facebook, developed during the Portuguese classes. The analysis of news production and reporting, plus the comments made on the digital platform, enable linguistically show that there is no rigid boundary between writing practices of focused on writing culture and those of digital culture, as they suppose many educators. Furthermore, show that social networks in school can work as collaborators in a more efficient and meaningful writing instruction for all involved.
\end{abstract}

Keywords: teaching of Portuguese language, literacies, digital literacy, facebook

Recebido em 14/04/2016. Aceito em 23/05/2016. Publicado em 31/05/2016. 


\section{INTRODUÇÃO}

Sabe-se que hoje, principalmente com a popularização da web $2,0^{1}$, surgiram novas práticas de escrita associadas à tecnologia digital, à multi/hipermodalidade. Por sua vez, as práticas escritas escolares, que não fazem uso das novas tecnologias e de seus recursos, têm se distanciado muito daquelas que são as mais familiares aos adolescentes fora do ambiente escolar. Ou seja, parte considerável das práticas extraescolares que envolvem a escrita, cotidianamente, não tem, para os alunos em geral, qualquer relação com as atividades de escrita escolares.

A escola, ainda que privilegiando as atividades sulcadas na tradição grafocêntrica, é um local de encontro entre aqueles considerados nativos digitais e imigrantes digitais (PRENSKY, 2001) ${ }^{2}$. Os primeiros são aqueles que já nasceram em um mundo completamente envolvido pelo avanço tecnológico. Para esses, é quase que impensável realizar uma pesquisa exclusivamente por meio de bibliotecas, onde inúmeros livros estão catalogados e à disposição de quem os queira consultar. Já os segundos, os imigrantes digitais conheceram as bibliotecas bem de perto, e foram inseridos no mundo digital depois de um percurso percorrido exclusivamente no mundo grafocêntrico, por isso podem não estar tão habilitados/familiarizados com todos os recursos digitais provenientes da web 2.0.

A construção dessa suposta fronteira, professores, imigrantes digitais de um lado e alunos, nativos, de outro, funciona como empecilho para as possibilidades de diálogo entre educando e educador. A tentativa de fazer os alunos escreverem sempre a partir de propostas da tradição escolar não têm oferecido bons resultados para o ensino. Tal divisão não tem contribuído para um ambiente propício para o ensino/ aprendizagem. Caso extremo foi o de

\footnotetext{
*Artigo elaborado a partir dos resultados da dissertação de mestrado de Paulo César Gonçalves, sob orientação da Profa. Dra. Edilaine Buin, intitulada "A tecnologia no ambiente escolar: análise do desenvolvimento de uma proposta de escrita no Facebook", defendida em agosto de 2015 no Programa de Pós-Graduação em Letras da Universidade Federal da Grande Dourados.

${ }^{1}$ Sobre o conceito de Web 2.0, aceitamos o seguinte argumento: "Diferentemente do que ocorria na Web 1.0, com a consolidação e o acelerado crescimento da internet nos últimos anos, a partir do advento da Web 2.0, novos mecanismos foram sendo criados, possibilitando novas condições técnicas e socioculturais para a ampliação das práticas comunicativas no mundo digital. Nesse novo ambiente, o usuário pode controlar os próprios dados. Na nova rede, há, portanto uma arquitetura de participação que inclui funcionalidades que possibilitam às pessoas não apenas receber, mas também publicar informações no sistema" (PINHEIRO, 2013, p.77).

${ }^{2}$ Sobre esse conceito, Prensky enfatiza que nossos estudantes de hoje são todos "falantes nativos" da linguagem digital dos computadores, vídeo games e internet. Então aqueles que não nasceram no mundo digital, mas em alguma época de suas vidas, ficaram fascinados e adotaram muitos ou a maioria dos aspectos da nova tecnologia são, e sempre serão comparados a eles, sendo chamados de imigrantes digitais (PRENSKY, 2001, p. 02).
}

[112] 
uma professora do interior de São Paulo agredida por um aluno ao proibir o acesso ao Facebook $^{3}$ durante a aula, como revelou a notícia publicada no Jornal Eletrônico G1 (AMYUNI, 2013) ${ }^{4}$, em 24 de agosto de 2013. Desconsiderando as questões disciplinares e éticas desse caso, percebemos o quanto o Facebook é visto como perturbador daquilo que a maioria dos profissionais da educação considera como a ordem correta do ensino.

A partir da exposição de uma proposta de escrita - a produção de um jornal virtual no Facebook $^{5}$ - em um $2^{\circ}$ ano do ensino médio, formado por 12 adolescentes entre 15 e 17 anos de idade, de um distrito rural, Santa Terezinha, de Itaporã-MS, e de parte de seus resultados, intencionamos inspirar uma reflexão em torno de novas possibilidades de trabalhos que contribuam para eliminar o abismo entre práticas de escrita escolares e não escolares.

A plataforma Facebook foi escolhida por ser a mais utilizada atualmente pelos alunos de Santa Terezinha, segundo relato de alunos e de profissionais que trabalham na escola. Assim, este artigo analisa alguns dados da produção do jornal virtual nessa plataforma. Antes, porém, de chegar aos dados, tecemos algumas considerações acerca das modalidades oral e escrita da linguagem e as redes sociais, e situamos o Facebook como uma ferramenta educacional.

\section{LINGUAGEM E REDES SOCIAIS}

Estudos voltados para a aquisição e o ensino da escrita vêm apontando-a como uma modalidade heterogeneamente constituída, como postula Corrêa (2004). Em sua proposta, Corrêa considera que o reconhecimento da heterogeneidade da escrita pode colaborar para a mudança de pensamento dos envolvidos no processo de ensino da linguagem, os quais, por vezes, acreditam que se deve evitar a interferência do oral no escrito.

\footnotetext{
${ }^{3}$ Conforme explica a própria página virtual do Facebook https://www.facebook.com/FaceBrasilOficial/info, trata-se de uma rede social lançada em 4 de fevereiro de 2004. Foi fundado por Mark Zuckerberg, Dustin Moskovitz, Eduardo Saverin e Chris Hughes, ex-estudantes da Universidade Harvard. É gratuita para os usuários e gera receita proveniente de publicidade, incluindo banners e grupos patrocinados. Cria-se perfis que contêm fotos e listas de interesses pessoais, trocando mensagens privadas e públicas entre si e participantes de grupos de amigos. A visualização de dados detalhados dos membros é restrita para membros de uma mesma rede ou amigos confirmados, ou pode ser livre para qualquer um. No começo, era destinada apenas a estudantes; hoje, aponta-se para 1,23 bilhão de usuários em todo o mundo. Fonte: https://www.facebook.com/FaceBrasilOficial/info Acesso em 30 maio 2015.

4 Disponível no link: http://g1.globo.com/sp/sao-carlos-regiao/noticia/2013/08/professora-barra-acessofacebook-e-leva-vassourada-em-sala-de-aula-pirassununga.html Acesso em 26 set. 2014.

${ }^{5}$ Página disponível no link: https://www.facebook.com/jv.st.3
} 
As conversas online e postagens em redes sociais, mediadas pela escrita no computador, desestabilizam ainda mais as diferenças entre oralidade e escrita. Vejamos, por exemplo, os comentários, retirados de páginas dos sujeitos em questão (seguem apenas as iniciais dos nomes originais):

(01) MM kkkk!! Olha o Lucho se apoiando na C. Se isso cai...

JT GMBF., aqui vc tah igual aquele boneco avatar do Wii, kkkkkk, não parece?

GMBF kkkkkkkkk

GMBF Pior que parece

J.K. kkkkkkkkkkkkk $;$

MM Turma boa!

O texto abaixo também é um exemplo:

(02) Aprendi a levantar a minha cabeça .. a ostrar que antes de tudoo, tenho amor próprio, e tudoo devoo a tii!

Me reergueu .. me mostrou o caminho, e colocou DEUS nele :)

"Amigos, para sempre bos amigos que nasceram pela fé, amugos pra

sempre .. para sempre amigos sim SE DEUS QUISER “oonde tudo

começou .. ***

e pra sempre vai ser!

Manano meu, mano lindo ! Que hoje seja mais que um simples

aniversário ! Que você reflita.. que você construa, que você realize ..

teus objetivos e sonhos ! Que você não me abandone nunca

mais que acima de tudo ...que você seja muito ... mais muuuuuito feliz !

Uma lágrima rolaando e uma porrada na cara do fdp qe a fez cair !!!

EU TE AAAAAAAAMO ! - com PR

Os recursos típicos do suporte digital - carinhas, alongamento de vogais etc. remetem a expressões de uma conversa face a face, o que pode levar a se dizer que se trata de um texto muito próximo da fala; contudo, é escrito.

Nesse sentido, Signorini (2001) prefere não falar de texto escrito com marcas de oralidade (ou texto oral com marcas de escrita), mas de linguagem, situando a escrita como "uma fase de um processo contínuo, um elo de uma cadeia em fluxo: a das produções de linguagem que dão sentido e forma à realidade social” (p. 126). Ou seja, a autora explica que o texto é resultado de uma etapa que alavanca outras. Transcrevendo suas palavras, "uma fase coisificada" de um processo contínuo mais amplo e sempre em fluxo.

Isoladamente, os comentários não dizem nada ( $\mathrm{e}$, assim, são tomados para exemplificar um uso inadequado da língua, reforçando o abismo entre diferentes práticas de escrita). Apenas se constituem no vínculo que estabelecem com o texto que os originou; a postagem é um ponto de uma cadeia maior da linguagem em fluxo. E ambos parecem ser uma pequena "fase coisificada", nos termos de Signorini, ou um congelamento ou uma cena capturada da linguagem em fluxo. 
Embora a autora opte por falar em uma "única" linguagem em fluxo, preferindo não separar oralidade de escrita, ela também concorda com Corrêa em relação à sua heterogeneidade constitutiva. Ela fala de um "hibridismo": a escrita é sempre heterogênea (no caso dos exemplos, constituída por recursos que lhe são próprios e por outros que resgatam as interações orais), mas é o olhar de quem lê, do outro, que identifica ou não essa heterogeneidade (ver a respeito Signorini, 2012). Desse modo, a mesma postagem e/ou comentário pode ser avaliada de formas diferentes dependendo de quem lê e do envolvimento ou distanciamento em relação à situação enunciativa.

O Facebook, as outras redes e todos os lugares de socialização não virtuais, constituise pela linguagem que elabora experiências, organizando o discurso de uma forma específica, a partir de diferentes recursos. A enunciação nada mais é do que o produto da interação social, quer se trate de um ato de fala determinado por uma situação imediata quer por um contexto mais amplo, ou seja, pelo conjunto das condições de vida de uma determinada comunidade linguística. Conforme diz Bakhtin (1990), o texto, seja oral ou escrito, não existe por si próprio, mas atrelado às situações que o gerou - a palavra não pode ser analisada fora da vida:

Na realidade, não são as palavras o que pronunciamos ou escutamos, mas verdades ou mentiras, coisas boas ou más, importantes ou triviais, agradáveis ou desagradáveis, etc. A palavra está sempre carregada de um conteúdo ideológico ou vivencial. É assim que compreendemos as palavras e somente reagimos àquelas que despertam em nós ressonâncias ideológicas ou concernentes à vida (BAKHTIN, 1992, p. 95).

As "verdades ou mentiras", "as coisas boas ou más", "importantes ou triviais" podem manifestar-se linguisticamente em uma mixagem de diversas práticas de escrita - mais ou menos formais, mais ou menos informais. O que não seria diferente nas plataformas digitais, como é o caso do Facebook, que, em geral, é associado sempre à informalidade.

As ferramentas digitais possibilitam amplitude de interação, não imaginada em tempos atrás. Fabrício Marques (2012), em uma reportagem na revista FAPESP, afirma que o cotidiano dos pesquisadores está sofrendo o impacto das redes sociais, de softwares online, dos blogs, que possibilitam novas parcerias, aceleram o intercâmbio de informações e garantem acesso instantâneo aos dados científicos de seu interesse. A matéria "Curtir e compartilhar" fala do sucesso da rede ResearchGate, com mais de 1,5 milhão de pesquisadores inscritos (35 mil no Brasil), para facilitar a comunicação e trocar experiências entre pessoas que atuam na mesma área. 
Marques explica que o ResearchGate "combina elementos de redes sociais consagradas como o Facebook e o Twiter, ou a profissional LinkedIn, com perfis dos membros, comentários, grupos e botões "curtir" e "compartilhar". Observa, no entanto, que não há espaço para "fotos de bebê, vídeos de gatos e autoelogios", como observou a reportagem do jornal The new York Times. A rede é restrita para cientistas e suas discussões. Essa rede social também faz a função da Plataforma Lattes no Brasil. Talvez seja por isso que o Brasil possui menos adeptos - os pesquisadores alimentam a plataforma Lattes, mas o diálogo científico também acontece nas redes sociais.

Saindo do âmbito científico, podemos afirmar que nem só as futilidades, tais como foto do prato de comida, imagens que visam à autoafirmação, comentários sobre a rotina, alimentam o Facebook. Os usuários escrevem longos textos, homenageiam familiares, criticam acontecimentos diversos, protestam contra maus tratos de animais, agregam pessoas no mundo real para um fim determinado, divulgando eventos importantes etc.

Em uma página do Facebook, formada de postagens e comentários, é fácil visualizar a heterogeneidade da escrita. E sua forma híbrida não é "desprivilegio" daqueles que ainda estão aprendendo a escrever. As redes sociais de adultos letrados funcionam dessa forma: em geral posta-se uma mensagem respeitando a forma padrão e abusa-se do internetês nos comentários.

Pelo que percebemos, entre as inúmeras possibilidades do Facebook, os doze alunos aqui focalizados, que representam outros da comunidade, utilizam frequentemente esta rede social para postar textos e fotos, conversar com os colegas, compartilhar poemas, entre outras. E o que fica claro é que buscam continuamente manter a interação por meio da escrita, ainda que por breves comentários ou simplesmente por carinhas e risadinhas.

Sem dúvida, a internet e os recursos tecnológicos são extremamente utilizados pelos jovens do distrito de Santa Terezinha. Praticamente todos os alunos, que vivem em uma comunidade tipicamente rural, estão inseridos no mundo virtual, como usuários e produtores. Utilizam diariamente os recursos tecnológicos como lazer, sendo eles: redes sociais (Facebook, Orkut), chats (msn, imbox), e-mail, blog, sites de notícias, jogos virtuais, entre outros. Nas redes sociais, tais jovens dialogam sobre assuntos diversos, como festas, viagens, paqueras, entre outros. Utilizam-se frequentemente de imagens e também pequenos textos. 


\section{FACEBOOK COMO FERRAMENTA EDUCACIONAL}

$\mathrm{Na}$ intenção de envolver os alunos em uma prática de escrita significativa, foi idealizado um projeto de produção de um jornal virtual. Este projeto foi desenvolvido durante as aulas de Língua Portuguesa com os alunos do $2^{\circ}$ ano do Ensino Médio da Escola Estadual Princesa Izabel, localizada no distrito de Santa Terezinha, município de Itaporã / MS.

O projeto aconteceu no terceiro bimestre letivo (entre julho e setembro de 2013), dentro do período de aula regular dos alunos, ou seja, no período noturno. Trata-se do desenvolvimento de um jornal virtual dentro do Facebook, em que os alunos tiveram a oportunidade de escrever sobre temas diversos relacionados à região onde vivem. O desenvolvimento desse jornal cumpriu integralmente a aplicação dos conteúdos exigidos pelo Referencial Curricular do Ensino Médio da Secretaria de Estado de Educação de Mato Grosso do Sul referentes ao terceiro bimestre, que previa o trabalho com os gêneros textuais (notícias, reportagens, entrevistas, descrições, etc.).

Um dos autores deste artigo, na época, atuou professor regente, em parceria com a professora em serviço durante um bimestre. Como a escola já lhe era familiar, o professor encontrou facilidade junto à direção da escola e à professora titular para ministrar aulas por um bimestre, para a turma do $2^{\circ}$ ano do Ensino Médio. Obviamente, como o trabalho foi desenvolvido em horário regular de aulas, algumas situações típicas do cotidiano que fazem com que a escola não tenha aula normal em alguns dias foram enfrentadas: paralisação, formação continuada, comemoração da Semana da Pátria, jogos escolares, entre outras.

A Sala de Tecnologias Educacionais (STE) é de uso comum de todas as disciplinas. Assim, parte das atividades foi realizada em sala de aula e parte na STE. A primeira versão de todos os textos foi escrita no papel e, depois de realizadas as correções, os alunos faziam a reescrita no computador. Muitas vezes os alunos iniciavam a digitação na sala de tecnologias da escola, mas, devido ao pouco tempo, continuavam seus textos em casa.

Para manter a comunicação permanente com os alunos, utilizamo-nos de duas plataformas virtuais na realização deste trabalho: o e-mail e o Facebook. O e-mail foi a ferramenta virtual utilizada para que os eles enviassem seus textos digitados antecipadamente para que o professor fizesse as análises e trabalhasse novamente com eles em sala de aula. Após as correções, os alunos refaziam e enviavam novamente para o e-mail criado para o projeto. Posteriormente, os textos eram publicados no Jornal Virtual, na página criada para 
dar suporte às produções dos alunos (https://www.facebook.com/jv.st.3). Após a postagem, os alunos, bem como todos os "amigos" adicionados, poderiam opinar livremente sobre os textos.

\section{OS REDATORES E SUAS APRESENTAÇÕES PESSOAIS}

A primeira proposta desenvolvida visava à apresentação dos redatores do jornal - o professor solicitou que elaborassem uma autodescrição, em que focassem a importância das tecnologias em suas vidas. Embora o produto final fosse um jornal virtual, foi consensual entre alunos e professores (e ninguém colocou em questão outra possibilidade) que a primeira versão fosse redigida em papel e corrigida de modo corriqueiro. No texto que se segue, o tom de lápis mais acentuado e algumas sobreposições marcam a correção resolutiva (Ruiz, 2003) realizada pelo docente:

Figura 1. Apresentação de Altamiro ${ }^{6} \mathbf{1}^{\mathrm{a}}$ versão

Figure 1. Presentation of Altamiro - 1st version

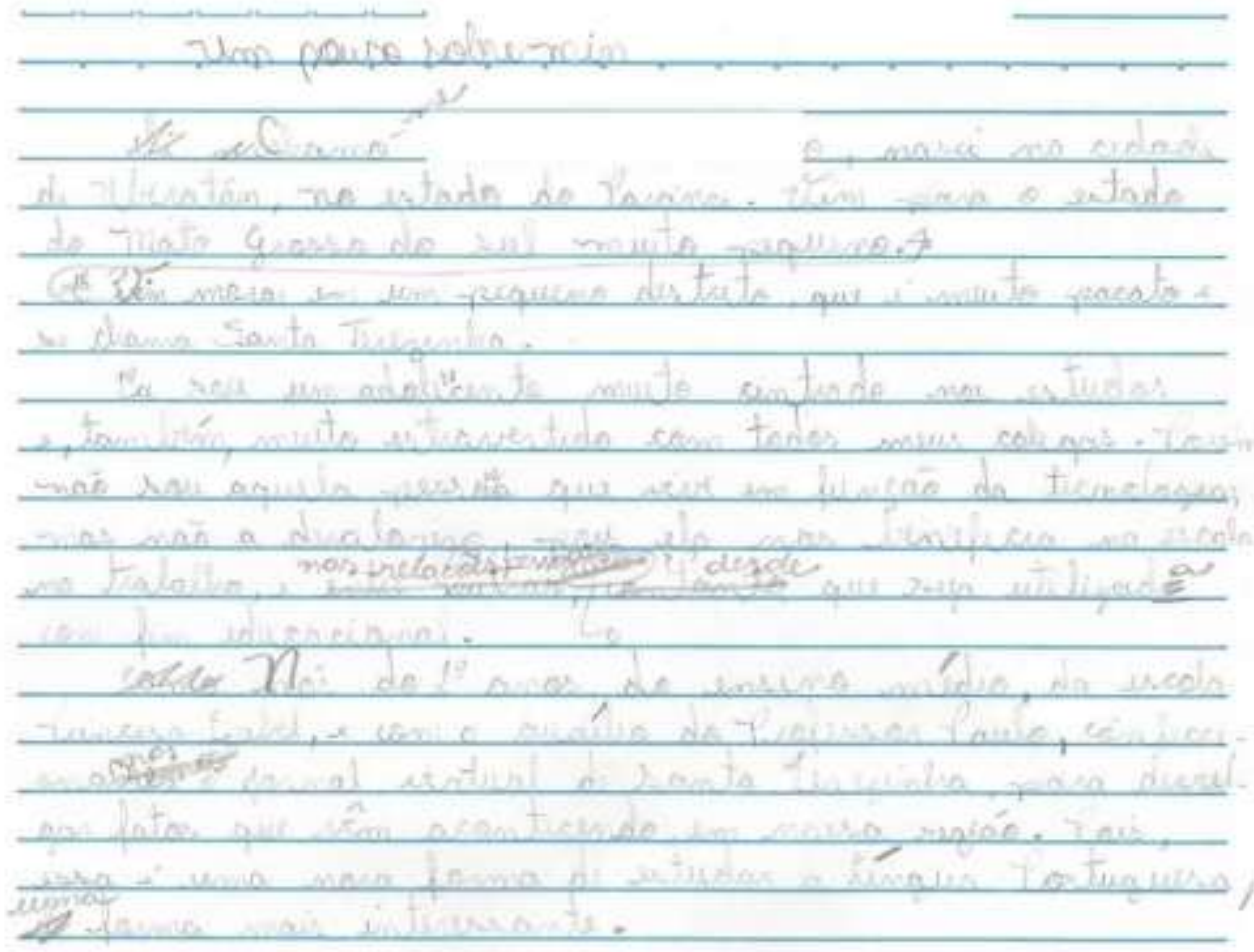

Um pouco sobre mim

Chamo-me Altamiro Roman Franco, nasci na cidade de Ubiratán, no estado do Parána. Vim para o estado do Mato Grosso do Sul muito pequeno.

\footnotetext{
${ }^{6}$ Os nomes dos alunos mencionados nesse artigo são nomes fictícios. As imagens (fisionomia) dos educandos também foram ocultadas.
} 


\begin{abstract}
Vim morar em um pequeno destrito, que é muito pacato e se chama Santa Terezinha.
Eu sou um adolecente muito centrado nos estudos e, também, muito estrovertido com todos meus colegas. Porém, não sou aquela pessoa que vive em função da tecnologia, mas não a desvalorizo, pois ela nos beneficia na escola, no trabalho e nas relações pessoais, desde que seja utilizada com fim educacional.

Nós do $2^{\circ}$ ano do ensino médio, da escola Princesa Izabel, e com o auxílio do Professor Paulo, confeccionamos o jornal virtual de Santa Terezinha, para divulgar fatos que vêm acontecendo em nossa região. Pois, essa é uma nova forma de estudar a Língua Portuguesa, uma forma mais interessante.
\end{abstract}

\title{
Transcrição do texto da Figura 1
}

O professor acrescenta a maioria das vírgulas, sobrepõe letras maiúsculas no início de períodos e parágrafos, indica com uma flecha a junção do segundo parágrafo com o primeiro. No terceiro parágrafo, troca "e entre outras, contanto que seja utilizado com fim educacional" por "nas relações pessoais, desde que seja utilizada com fim educacional". Como vemos e, embora estivessem falando de tecnologia digital e produzindo textos para rede social - e ainda que todos ali, inclusive o professor, se enquadrasse na categoria de nativos digitais - iniciam a tarefa pela lógica da cultura grafocêntrica. Além disso, o diálogo estabelecido via correção visa apenas a aspectos formais do texto, desconsiderando-se questões relacionadas ao teor do próprio dizer.

Somente na etapa seguinte, e sob o aval do professor, é que digitam os textos no computador e, na sequência, inserem fotos pessoais. Postados os textos, inicia-se o diálogo na plataforma:

Figura 2. Apresentação de Altamiro - $2^{\mathrm{a}}$ versão

Figure 2. Representation of Altamiro - 2nd version

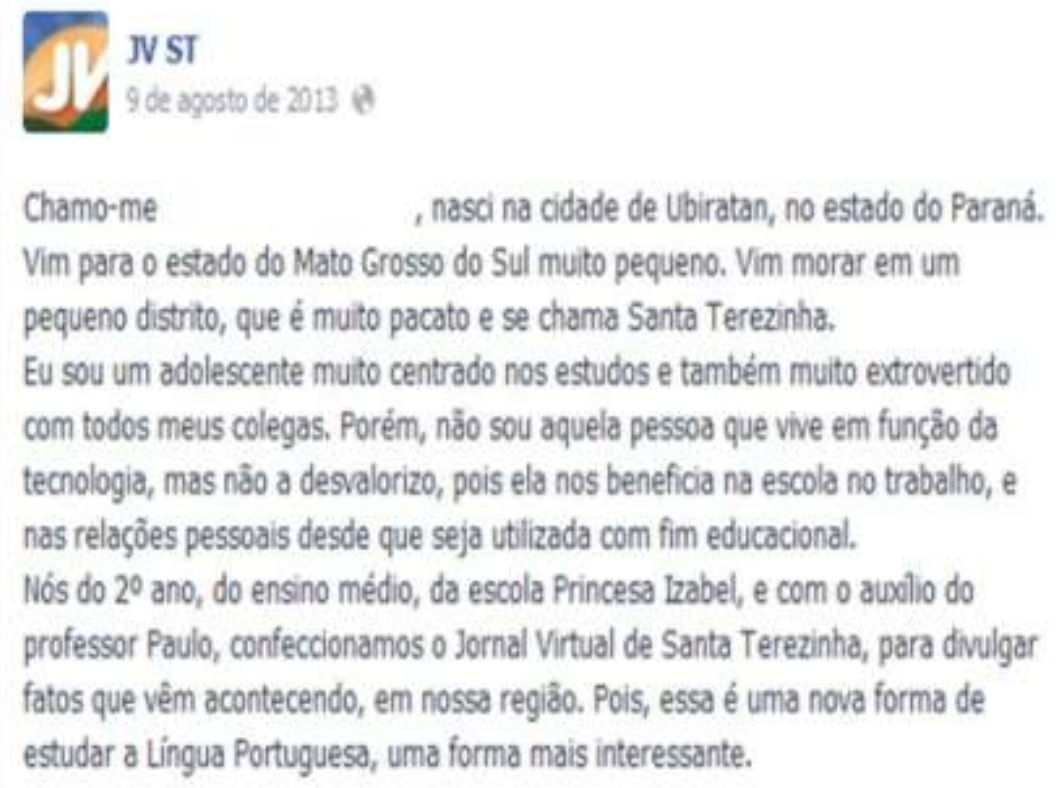




\section{Figura 3. Comentários a partir da apresentação de Altamiro}

Figure 3. Comments from the presentation Altamiro

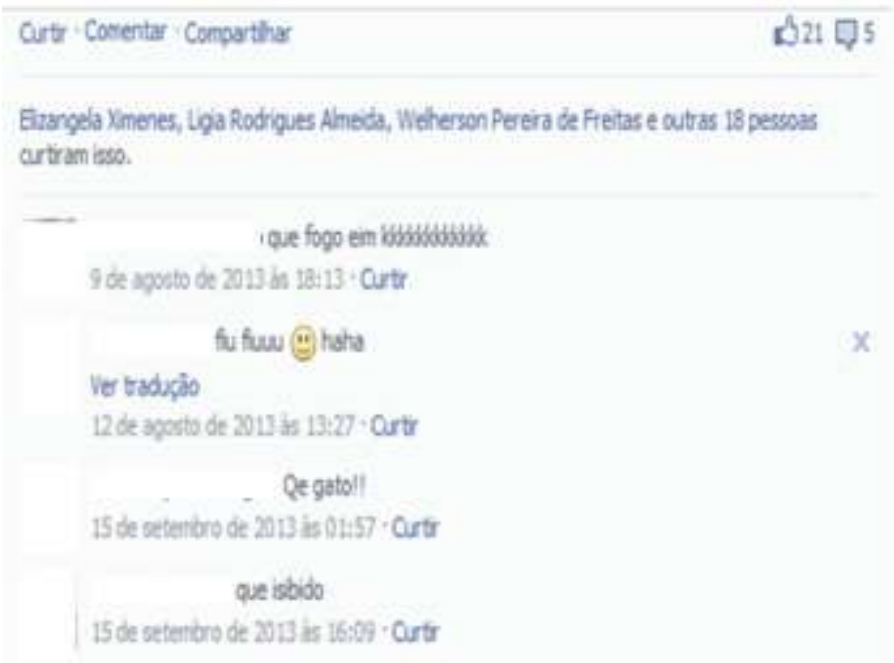

O Altamiro da descrição é centrado nos estudos e também muito extrovertido com os colegas; a imagem (que optamos por não colocar aqui), que mostra o rapaz em uma cachoeira, em pose, sentado em uma pedra, revela características não verbalizadas na escrita: alguém que gosta muito na natureza, esportista, pelo aspecto físico, charmoso. Ou seja, a foto revela características não verbalizadas na escrita.

Os comentários (fogo eim kkkkkk, fiu fiuuи (-) haha, Que gato, que isibido) dirigem-se à imagem (não ao texto escrito) e podem estar revelando a surpresa que a foto causou aos colegas, que tinha como referencial outra imagem do garoto. Como um dos autores conhece bem o aluno (já foi seu professor por vários anos), podemos dizer que ele, na realidade, é de fato estudioso, mas não se mostra extrovertido; é, ao contrário, bastante tímido. A plataforma parece possibilitar a criação, na conjunção escrita e imagem, de um Altamiro diferente de como a aluno se mostra na realidade, ou de uma face diferente daquela apresentada até então, ou, talvez, de uma personagem que concentra aquilo que ele gostaria de ser.

A internet possibilita/facilita a "criação" de máscaras, pois é possível revelar-se como sendo outro, agir como se fosse outro, construindo uma identidade diversa daquele pela qual se é reconhecido no mundo real (Moita Lopes, 2012). O aluno Altamiro parece experimentar, ainda que inconscientemente, uma nova performance, para si mesmo e para os outros, e experimentar seus efeitos semânticos - dos quais os comentários dos colegas nos dão dica, 
mas que, estando no mundo virtual e não face a face, ele tem a opção de não responder ou de se proteger.

No caso de outra aluna, Luciana, a segunda versão digitalizada é igual à primeira, escrita a mão. Como os aspectos formais estão a contento do professor, ele não faz qualquer anotação. Tanto nesse caso, quanto em todos os outros, a correção é voltada apenas para aspectos formais, nunca para questões de construção dos sentidos produzidos, tendo em mente um interlocutor. Algo que poderia ser apontado pelo professor é o fato de que, embora também tivesse como tarefa escrever uma apresentação pessoal (pois a ideia principal era se fazer conhecida), a aluna simplesmente optou por não aparecer. Ela só revela o nome, a idade e sua naturalidade, em menos de duas linhas completas, o que não caracteriza uma “apresentação pessoal". Todo restante do texto dedica-se aos comentários sobre a tecnologia digital:

\section{Figura 4. Apresentação de Luciana - 1a versão} Figure 4. Luciana Presentation - 1st version

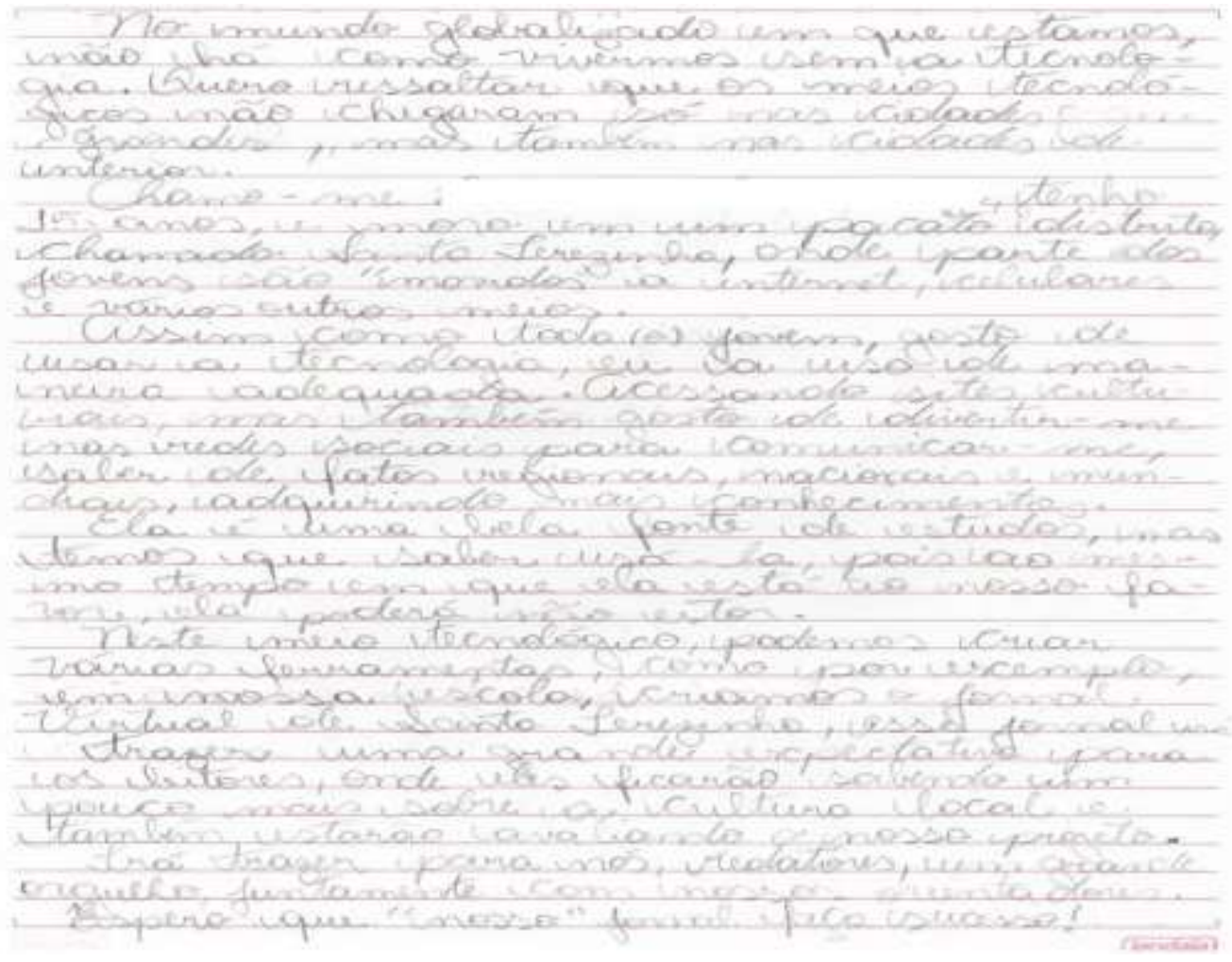

No mundo globalizado em que estamos, não há como vivermos sem a tecnologia. Quero ressaltar que os meios tecnológicos não chegaram só nas cidades grandes, mas também nas cidades de interior. Chamome Luciana de Lima Braga, tenho 15 anos e moro em um pacato distrito, chamado Santa Terezinha, onde parte dos jovens são "movidos" à internet, celulares e vários outros meios. Assim como toda (o) jovem, gosto de usar a tecnologia, eu a uso de maneira adequada. Acessando sites culturais, mas também gosto de divertir-me nas redes sociais para comunicar-me, saber de fatos regionais, nacionais e mundiais, adquirindo mais conhecimentos. 
Ela é uma bela fonte de estudos, mas temos que saber usá-la, pois ao mesmo tempo em que ela está ao nosso favor, ela poderá não estar.

Neste meio tecnológico, podemos criar várias ferramentas, como, por exemplo, em nossa escola, criamos o jornal Virtual de Santa Terezinha, esse jornal irá trazer uma grande expectativa para os leitores, onde eles ficarão sabendo um pouco mais sobre a cultura local e também estarão avaliando o nosso projeto. Irá trazer para nós, redatores, um grande orgulho, juntamente com nossos orientadores. Espero que "nosso" jornal faça sucesso!

\section{Transcrição do texto da Figura 4}

\section{Figura 5. Apresentação de Luciana - Última versão} Figure 5. Luciana Presentation - Latest version

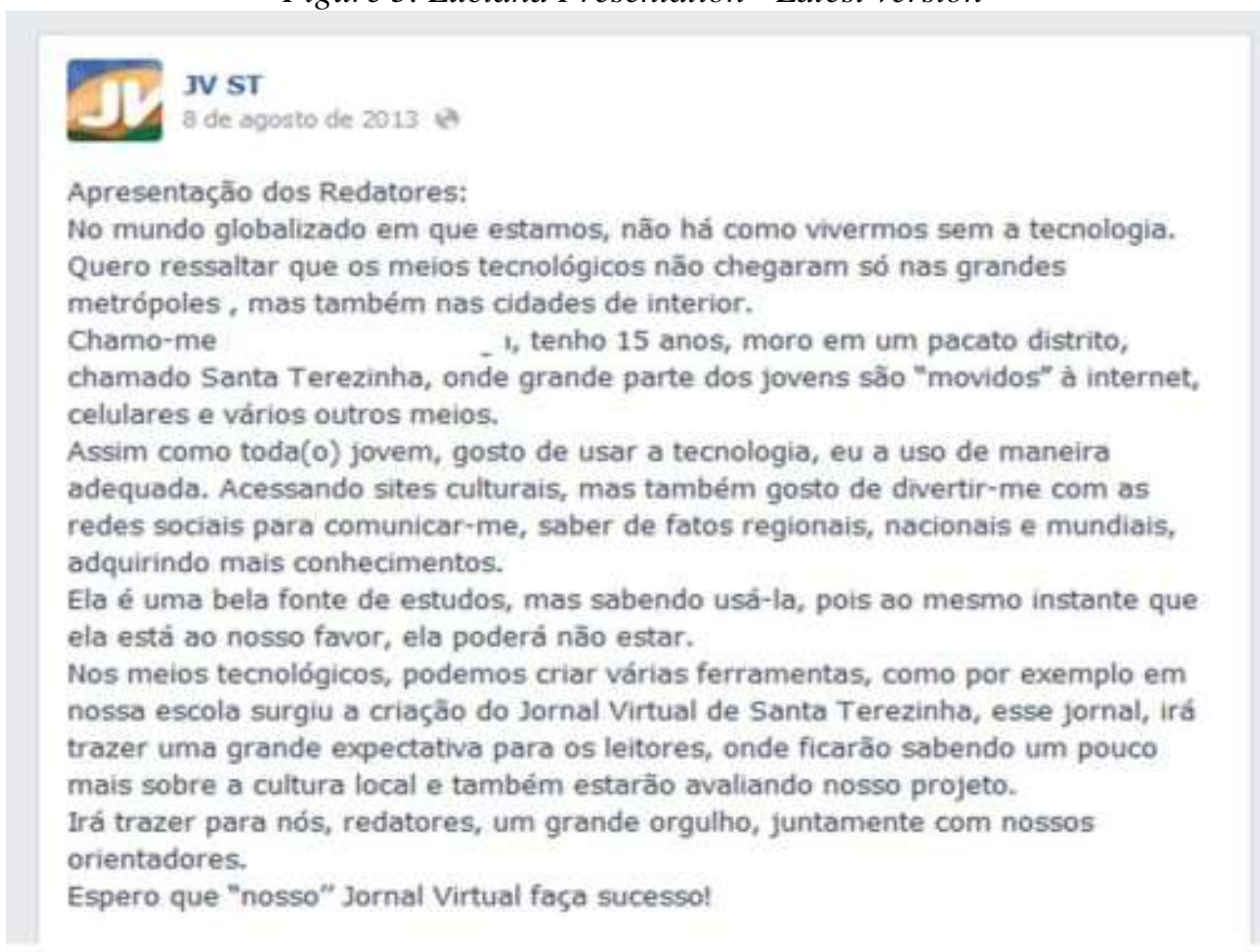

Interessante foi perceber a forma distinta de escrita dos próprios alunos neste suporte virtual, pois ao mesmo tempo em que procuravam manter a língua padrão nas matérias utilizavam-se de coloquialismos e do "internetês" nos comentários publicados, como vimos na apresentação pessoal do Altamiro e de Luciana.

Figura 6. Comentários sobre a apresentação de Luciana Figure 6. Comments on the presentation of Luciana

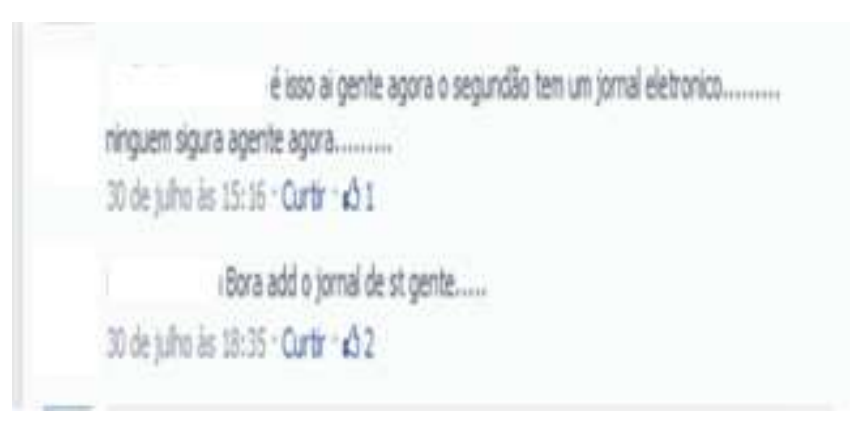


No caso da postagem de Luciana, é a própria autora do texto responde aos comentários dos colegas em de uma forma bem diferente daquela que usa para postar o texto: "Bora add o jornal de st gente". Quando o público alvo se limita aos colegas, a forma usada distancia-se mais da padrão. A mesma Luciana que redigiu a "apresentação" acima para o Jornal Virtual, posteriormente, diante de uma escrita extraescolar, publica um desabafo, a partir do qual se revela mais sobre si - uma pessoa sensível - do que na apresentação pessoal solicitada pela escola:

\section{Figura 7. Escrita espontânea de Luciana}

Figure 7. Spontaneous Writing Luciana

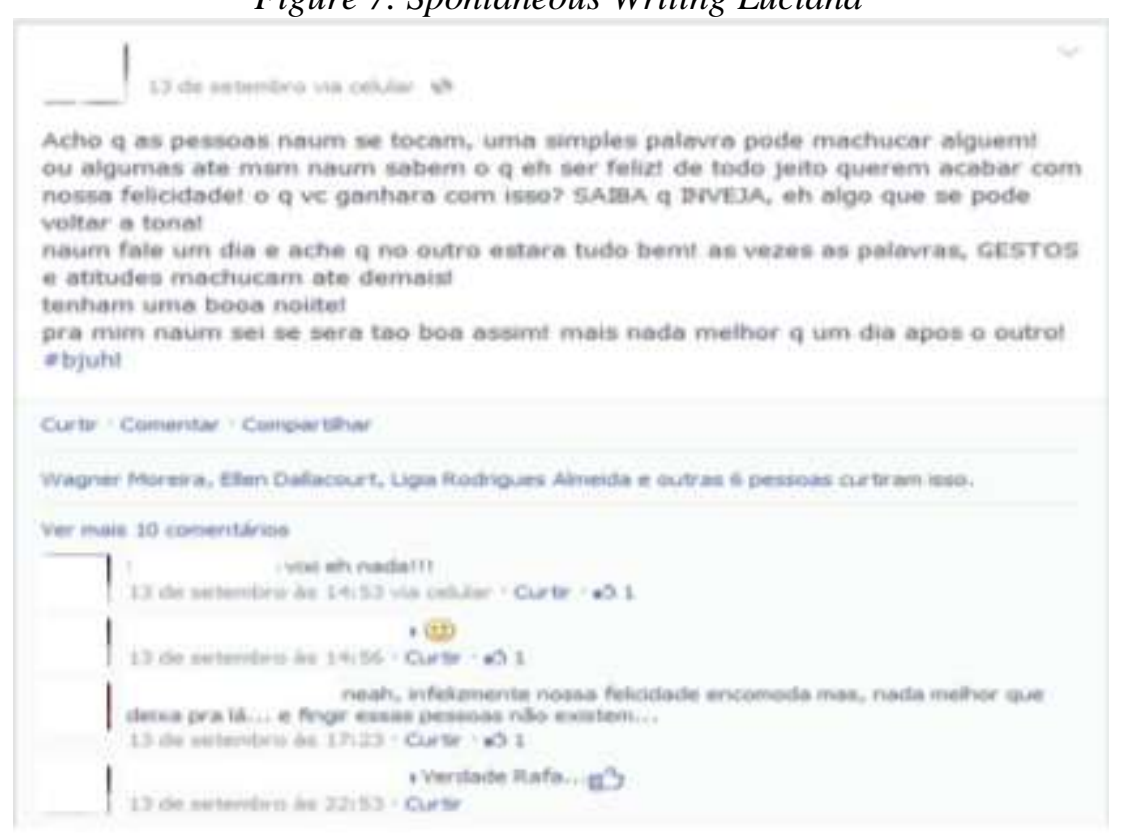

$\mathrm{Na}$ atividade proposta pela escola com bases na cultura grafocêntrica, logo na primeira versão escrita em papel, tanto Luciana como os outros alunos já apresentam uma linguagem diferente da que usam nos diálogos entre colegas - o que indica que têm consciência de seu público leitor, que não seria somente os colegas, mas qualquer pessoa da comunidade de Santa Terezinha. Percebemos ainda que parece haver a consciência de que há diferentes estratégias discursivas a serem utilizadas em diferentes momentos num mesmo suporte textual.

Embora muitas pessoas da comunidade tenham "curtido" os textos, os comentários acabaram ficando entre os colegas e variaram entre "elogios" para os textos/imagens e dizeres a respeito de sua construção. A ferramenta, longe de perturbar a escrita escolar, possibilita constatar que os adolescentes sabem usar eficientemente a língua de acordo com o contexto. 


\section{NOTÍCIAS E REPORTAGENS}

Depois das apresentações pessoais, os alunos seguiram com a produção de notícias e reportagens. As versões da reportagem de Lúcio sobre a Agroindústria Doce Conquista mostram como a escrita tem bases grafocêntricas. As supressões, indicativas do trabalho do sujeito com a linguagem (atividade epilinguística), acontecem na versão em papel e não na versão digital. Não é possível recuperar pelos sinais de apagamento o que o aluno havia posto antes nos vários espaços em branco, mas pode-se dizer que tais espaços indicam reelaboração por supressão, conforme é possível observar no segundo e terceiro parágrafos:

Figura 8. Texto sobre a Agroindústria Doce Conquista $-1^{\mathrm{a}}$ versão Figure 8. Text on Agroindústria Doce Conquista - 1st version

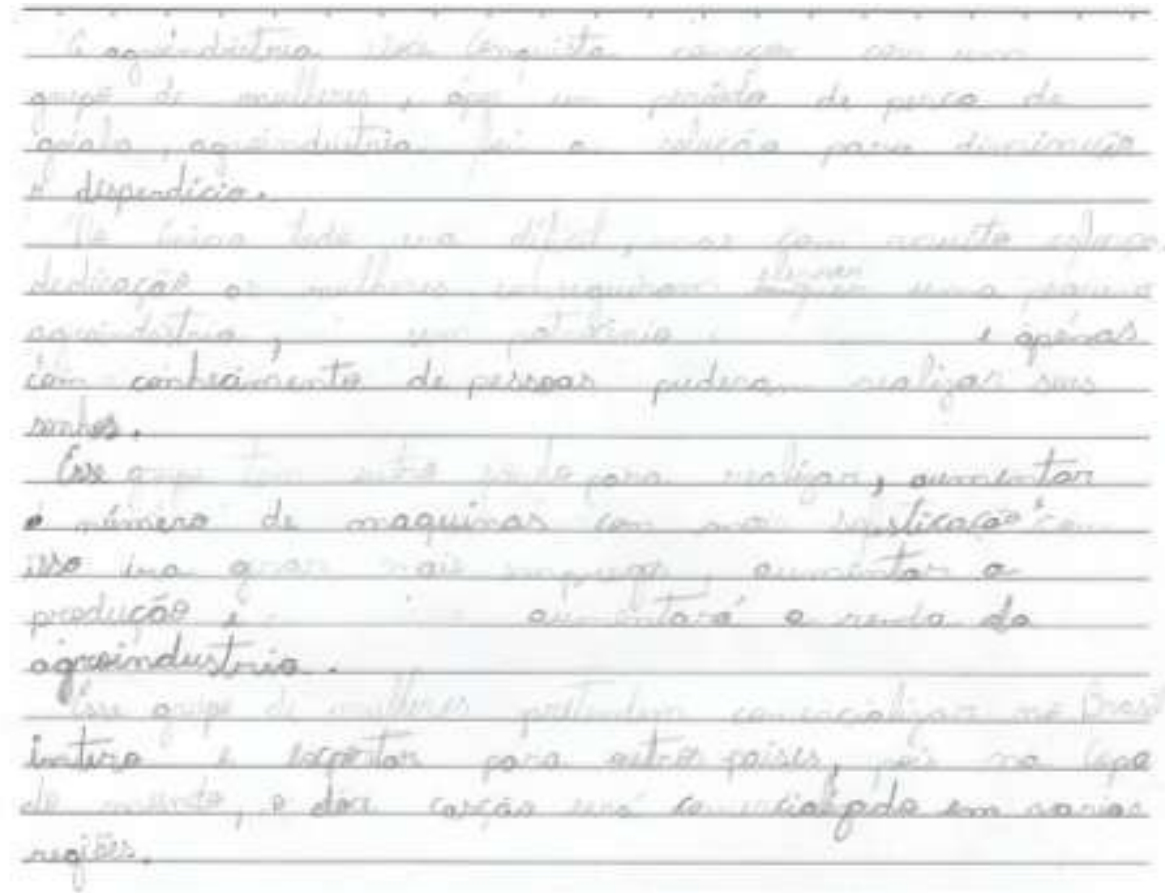

A agroindústria Doce Conquista começou com um grupo de mulheres, após um período de perca de goiaba, agroindústria foi a solução para diminuir o disperdício.

No início tudo era díficil, mas com muito esforço, dedicação as mulheres conseguiram elevar uma pequena agroindústria, sem patrocínio e apenas com conhecimento de pessoas puderam realizar seus sonhos.

Esse grupo tem outro sonho para realizar, aumentar o número de maquinas com mais sofisticação e com isso ira gerar mais empregos, aumentar a produção e aumentará a renda da agroindustria.

Esse grupo de mulheres pretendem comercializar no Brasil inteiro e exportar para outros países, pois na Copa do Mundo, o doce cascão será comercializado em varias regiões.

Transcrição do texto da Figura 8 
A versão digital é exatamente igual a do papel, o que confirma que o aluno elaborou de fato o texto pelo modo tradicional, ou seja, pela lógica da cultura grafocêntrica. $\mathrm{Na}$ verdade, as duas versões são redigidas no papel e apenas se copia a última no computador:

Figura 9. Texto sobre Agroindústria Doce Conquista - $2^{\mathrm{a}}$ versão

Figure 9. Text on Agroindústria Doce Conquista - 2nd version

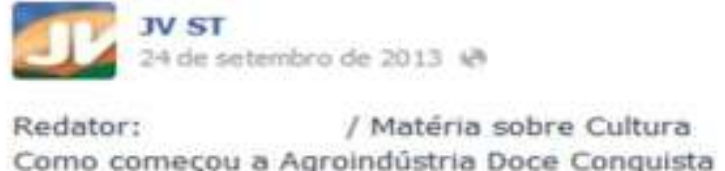

A Agroindûstria Doce Conquista comecou com um grupo de mulheres, após um periodo de perda de goiaba, logo a agroindústria foi a solução para diminuir o desperdício.

No inicio tudo era dificil, mas com muito esforşo e dedicaşão as mulheres conseguiram elevar uma pequena agroindûstria, sem patrocínio e apenas com conhecimento de pessoas puderam realizar seus sonhos.

Esse grupo tem outro sonho para realizar, aumentar o número de máquinas com mais sofisticação e com isso irá gerar mais empregos, aumentar a produção e aumentar a renda da agroindústria.

Esse grupo de mulheres pretendem comercializar no Brasil inteiro e exportar para outros paises, pois na Copa do Mundo, o doce cascão será comercializado em várias regizes.

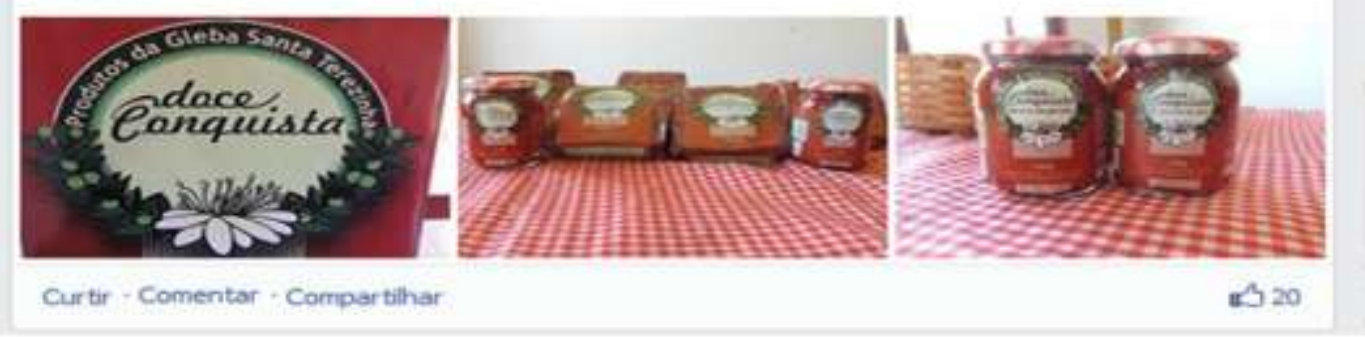

A novidade não se voltou para o fazer em si, moldado pela lógica do grafocentrismo, mas para o destino do produto final. Ao ser postado em rede social, não é apenas algo para ser lido e avaliado pelo professor, mas, além disso, para ser lido e apreciado por uma comunidade.

O texto sobre a Agroindústria Doce Conquista representa tantos outros, escritos individualmente por cada aluno da turma. Um deles, porém, foi produto de uma produção cuja proposta previa que fosse colaborativa ${ }^{7}$. Os alunos tiveram que buscar informações para escrever um texto que resgatasse a história da escola. A primeira versão constitui-se em uma mistura de gêneros discursivos e de mídias:

\footnotetext{
${ }^{7}$ Estamos entendendo "escrita colaborativa" a escrita negociada e realizada em grupo - no caso do exemplo aqui posto, cada um ficou responsável por pesquisar um assunto do tema geral e redigir uma parte do texto. Encontramos em Pinheiro (2012) que a Escrita Colaborativa é um empreendimento ativo e social que possui duas forças de impulsão inter-relacionadas: o grupo, como agente de apoio individual, e o participante, cujo envolvimento para colaborar repousa no seu interesse em partilhar com o grupo a realização das tarefas.
} 


\section{Figura 10. Escrita colaborativa sobre a escola - $1^{\text {a }}$ versão}

Figure 10. Collaborative Writing School - 1st version

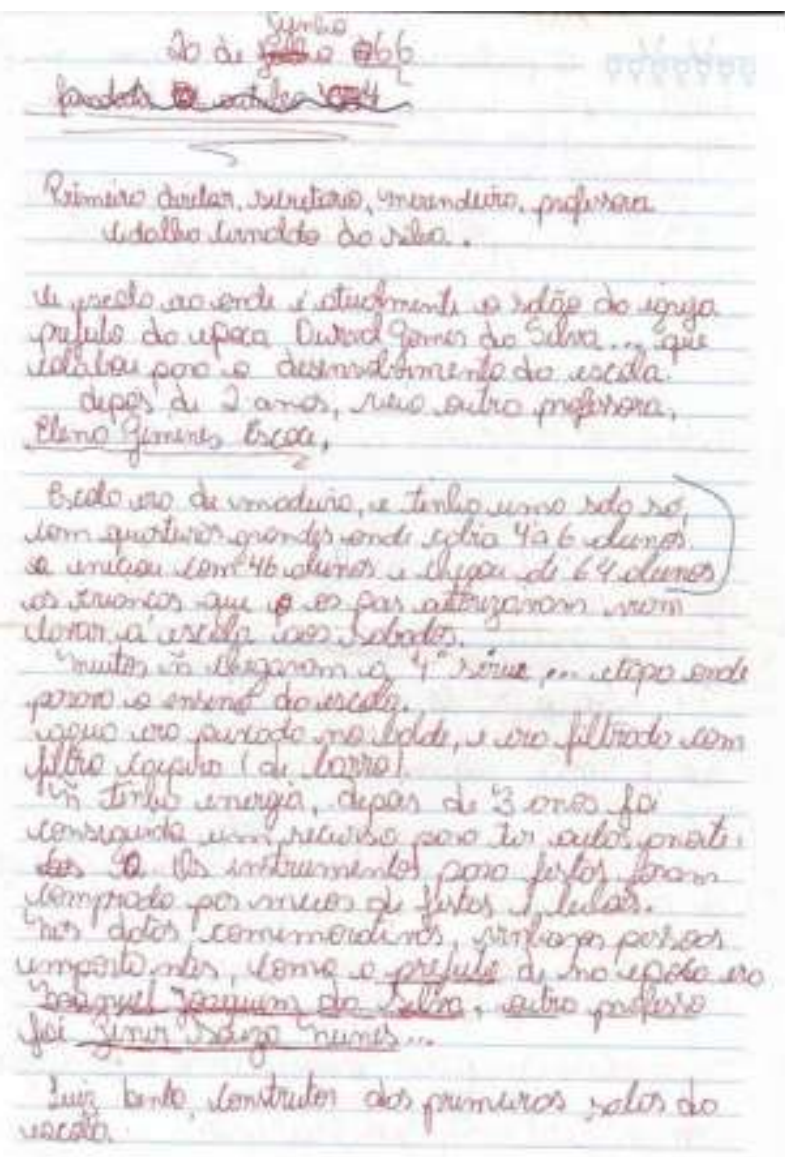

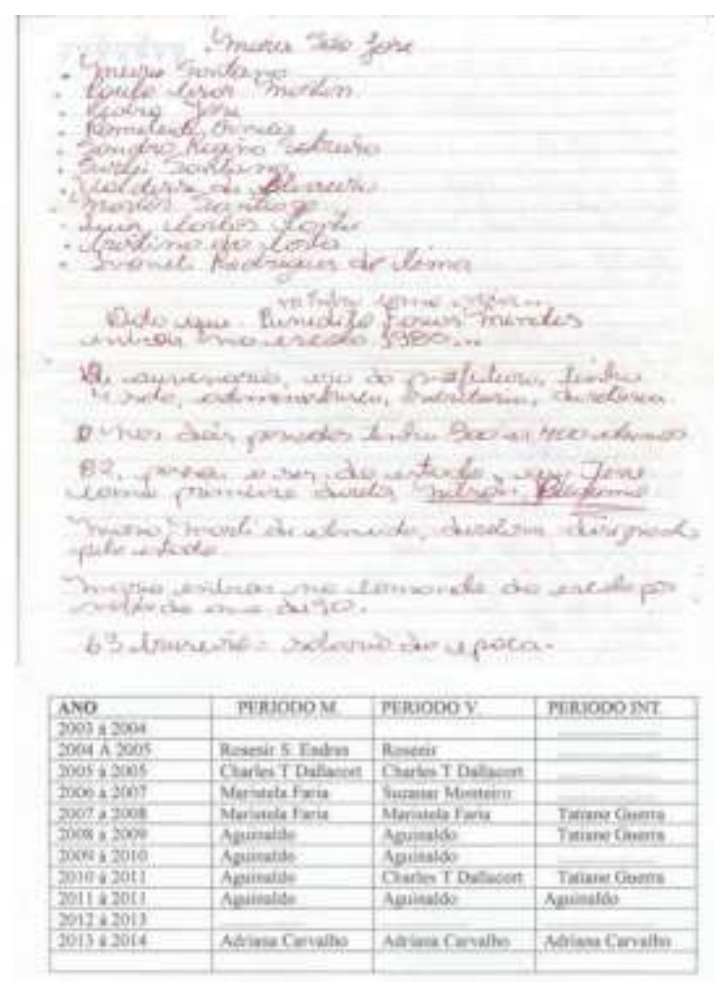

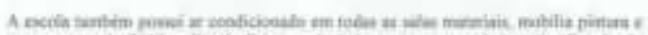

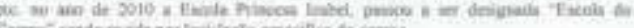

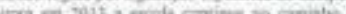

pay poes segir menips

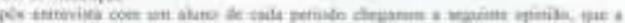

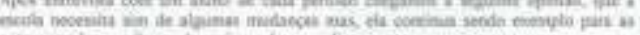

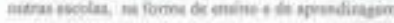

20 de junho 66

Primeiro diretor, secretario, merendeira, professora Adalha Arnaldo da Silva.

A escola era onde é atualmente o salão da igreja prefeito da epoca Durval Gomes da Silva... que colabou para o desenvolvimento da escola. Depois de 2 anos, veio outra professora, Elena Gimenes Escoce.

Escola era de madeira, e tinha uma sala só, com quarteiras grandes onde cabia 4 a 6 alunos as crianças que os pais autorizavam viam lavar á escola aos sabados.

Muitos ñ chegavam a $4^{\mathrm{a}}$ série... etapa onde parava o ensino da escola.

agua era puxada no balde, e era filtrada com filtro caipira (de barro)

$\tilde{N}$ tinha energia, depois de 3 anos foi conseguido um recurso para ter aulas a noite. Os instrumentos para festas foram comprado por meios de festas e leilões.

Nas datas comemorativas vinhanos pessoas importante, como o prefeito de na epoca era Manuel Joaquim da Silva, outro professo foi Zenir Souza Nunes...

Luiz bento, construtor das primeiras salas da escola.

. Maria São José

. Meire Santana

. Paulo Cesar Martin

. Pedro Jose

. Romeleida Prnica

. Sandra Regina Sobreira

. Sirlei Santana

. Valdirsi de Oliveira

. Marcos Santiago 


\section{. Luiz Carlos Cantu \\ . Cristina da Costa \\ . Ivoneti Rodrigues de Lima}

Entra como vigia... Data que Benedito Farias Mendes entrou na escola 1980...

De alvenaria, era da prefeitura, tinha 4 sala, administrativo, secretaria, diretoria

Nos dois periodos tinha 500 a 400 alunos

82 passou a ser do estado, que teve como primeiro diretor Nelson Picafumo.

Maria Marli de almeida, diretora designada pelo estado. Maria entrou no comando da escola por volta do ano de 90.

63 cruseiro $=$ salario da epoca

\begin{tabular}{|l|l|l|l|}
\hline Ano & Período M. & Período V. & Período Int. \\
\hline 2003 a 2004 & & & \\
\hline 2004 a 2005 & Rosenir S. Endres & Rosenir & \\
\hline 2005 a 2005 & Charles T. Dallacort & Charles T. Dallacort & \\
\hline 2006 a 2007 & Maristela Faria & Suzamar Monteiro & \\
\hline 2007 a 2008 & Maristela Faria & Suzamar Monteiro & Tatiane Guerra \\
\hline 2008 a 2009 & Aguinaldo & Aguinaldo & Tatiane Guerra \\
\hline 2009 a 2010 & Aguinaldo & Aguinaldo & \\
\hline 2010 a 2011 & Aguinaldo & Charles T. Dallacort & Tatiane Guerra \\
\hline 2011 a 2011 & Aguinaldo & Aguinaldo & Aguinaldo \\
\hline 2012 a 2013 & & & \\
\hline 2013 a 2014 & Adriana Carvalho & Adriana Carvalho & Adriana Carvalho \\
\hline
\end{tabular}

A escola também possui ar condicionado em todas as salas materiais, mobilia pintura e etc. no ano de 2010 a Escola Princesa Izabel, passou a ser designada "Escola do Campo" sendo regida por legislação específica do campo.

Agora em 2013 a escola continua no caminho para que possa seguir sempre rumo às mudanças.

Após entrevista com um aluno de cada período chegamos à seguinte opinião, que a escola necessita sim de algumas mudanças mas, ela continua sendo exemplo para as outras escolas, na forma de ensino e de aprendizagem.

\section{Transcrição do texto da Figura 10}

Observamos que parte do texto está escrita à caneta e parte é a colagem de uma folha impressa, organizada pelos próprios alunos. O texto é um composto de anotações diversas sobre a escola, concentradas na primeira página. Na segunda página, há listas de nomes de alguns profissionais, seguida de várias anotações (informações sobre pessoas, sobre salários etc.). Na sequência, há uma tabela impressa, com vários nomes (que identificamos como nome de diretores somente através da versão final). Abaixo da tabela, vem um trecho descritivo do patrimônio da escola e, no último parágrafo, uma espécie de conclusão, a qual lembra textos dissertativos (chegamos a seguinte opinião, que a escola necessita sim de algumas mudanças mas, ela continua sendo exemplo para as outras escolas, na forma de ensino e de aprendizagem). Já no rascunho, percebemos que não se trata de fato de escrita colaborativa, uma vez que cada um parece ter feito a sua parte independentemente dos outros. Ou seja, cada parte se integrou a outra para formar um todo, sem que houvesse negociação entre os participantes.

Nesse conjunto, materializado nessa primeira versão, é possível detectar o entrecruzamento de diferentes gêneros (anotação, lista, dissertação) e de diferentes práticas 
de escrita (Corrêa, 2004). A prática de escrita digital acomoda-se à prática de escrita no papel, uma vez que o(s) aluno(s) imprime(m) o que foi digitado e colam no papel em que está a parte escrita a caneta, compondo coletivamente a $1^{\text {a }}$ versão. Assim, esse dado evidencia um momento em que a força da cultura escrita digital se depara com a força da cultura grafocêntrica/escolar e se acomoda a ela.

A versão final foi apresentada, no Facebook, da seguinte forma:

\section{Figura 11. Escrita colaborativa sobre a escola - Última versão Figure 11. Collaborative Writing School - Latest version}

\footnotetext{
PIT IV ST

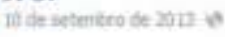

Escole Princesa isabel, semeando sonhos e cultivando direitos

Fundada em 20 de junho de 1966, a escola Mista Rural, atuaimente 6 chamade de Escola Estadual Prncesa izabel. Escola onde, antigamente; era localizado o saišo de festas da igreja; era composta per 46 alunos, cheganda a 64 alunos.

Ercola essa que trve como referincia done Adatha Amaldo of Silva, que teve as seguintes funçōes: diretora, secretairia, merendeira, professora e teve tambeim um papel mais importante, peis foi ela que escolheu o nome atual, (Pnncesa trabel). Depois de muita insistência on prefeito do época, senthor Durvol Comes do Silva, otendeu aos apelos trazendo a funciendria, Elena Gimenes Escoce, para ministrar aulas no ensino fundamental, primário.

Fiscamente a escola ero de modeiro e tinha somente ume sala, com carteras grandes, onde cabiam de 4 a 6 alunos a dógua servida pera os alunos era retirad manualmente do poça, e fitrada em filtros de barro, năo tinha energia eletrica. Aposs 3 anos foi conseguido recursos, pera que a escole podesse licenciar auls aneite.

Com o dinheire arrecadada nas festas, foran adquiridas verbas para a coenipra de instrumentos musicais, instrumentos pore a entiga fanfarre. Nas datos comentorativas, a escola recebia vistas importantes, corno prefectos e vereadores, depois de algum tempo com a chegada de novos aliuncs foi necessáric a canstrucbo de novas salas com o apoio de Luiz Bento. Prédio esse que tinta váries funç̧es: botel, igraja, a a propiria escola.

No mandato de Durval Comes da Silva for entregue um terreno, o qual futuramente serie construido a nova escolo. Com chegada de novo prefetto, Antonio Cordeiro Nieto, em 1977, iniciou-se a construçáo do antiga escola, com a aumento do saldino dos protessores que era de 99 cruzeros e passou para 215 cruzeires. Nio dia 8 de maio de 1978, inaugurou a nova escola, contanido com presensa do prefeito e sua esposa.

O gratsio iniciou em 1979, com os seguintes professores: Augusto Trobine, Aparecido Naitol, e Aucileia Marques. Em 1992 a escole passou a ser do estado e teve como primeira diretat Nelson Lopes, conhecido como (Cvelson Picafumo). Aiguns anos depois o prezado diretor teve que sair, dendo lugar a diretora designado pelo estado, Maria Marli de Aimeide. Marie comendou a dires lo de escol ate 0 ano de 1990. Nessa ipoca possula apenas o ensino fundamental, nōo possuí 0 ensino médio. Na ano de 1950, veio a professora de llaperă Mtaria Pereira Alves,
}

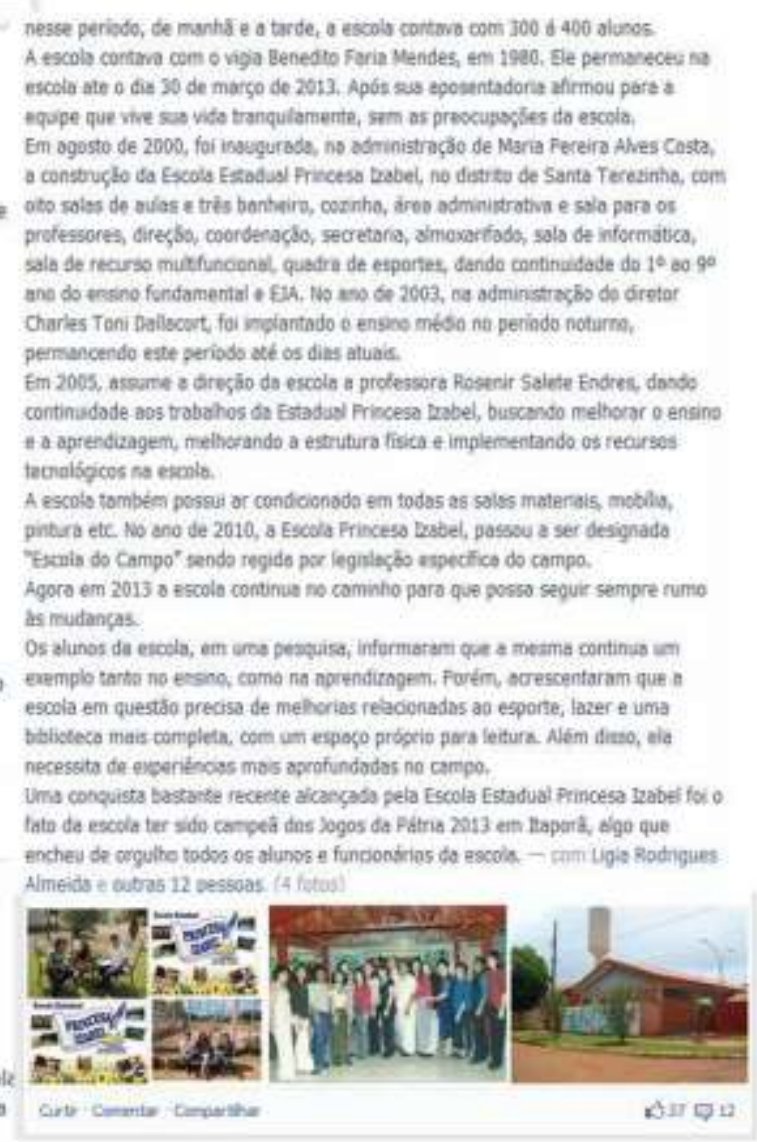

Escola Princesa Isabel, semeando sonhos e cultivando direitos

Fundada em 20 de junho de 1966, a escola Mista Rural, atualmente é chamada de Escola Estadual Princesa Izabel. Escola onde, antigamente, era localizado o salão de festas da igreja; era composta por 46 alunos, chegando a 64 alunos.

Escola essa que teve como referência dona Adalha Arnaldo da Silva, que teve as seguintes funções: diretora, secretária, merendeira, professora e teve também um papel mais importante, pois foi ela que escolheu o nome atual, (Princesa Izabel). Depois de muita insistência ao prefeito da época, senhor Durval Gomes da Silva, atendeu aos apelos trazendo a funcionária, Elena Gimenes Escoce, para ministrar aulas no ensino fundamental, primário.

Fisicamente a escola era de madeira e tinha somente uma sala, com carteiras grandes, onde cabiam de 4 á 6 alunos a água servida para os alunos era retirada manualmente do poço, e filtrada em filtros de barro, 
não tinha energia elétrica. Após 3 anos foi conseguido recursos, para que a escola podesse licenciar aula anoite.

Com o dinheiro arrecadado nas festas, foram adquiridas verbas para a compra de instrumentos musicais, instrumentos para a antiga fanfarra. Nas datas comemorativas, a escola recebia visitas importantes, como prefeitos e vereadores, depois de algum tempo com a chegada de novos alunos foi necessário a construção de novas salas com o apoio de Luiz Bento. Prédio esse que tinha várias funções: hotel, igreja, e a própria escola.

No mandato de Durval Gomes da Silva foi entregue um terreno, o qual futuramente seria construído a nova escola. Com chegada de novo prefeito, Antonio Cordeiro Neto, em 1977, iniciou-se a construção da antiga escola, com a aumento do salário dos professores que era de 99 cruzeiros e passou para 215 cruzeiros. No dia 8 de maio de 1978, inaugurou a nova escola, contando com presença do prefeito e sua esposa.

O ginásio iniciou em 1979, com os seguintes professores: Augusto Trobine, Aparecido Miltol, e Aucileia Marques. Em 1982 a escola passou a ser do estado e teve como primeiro diretot Nelson Lopes, conhecido como (Nelson Picafumo).

Alguns anos depois o prezado diretor teve que sair, dando lugar a diretora designado pelo estado, Maria Marli de Almeida. Maria comandou a direção da escola ate o ano de 1990. Nessa época possuía apenas o ensino fundamental, não possuía o ensino médio. No ano de 1980, veio a professora de Itaporã Maria Pereira Alves, nesse período, de manhã e a tarde, a escola contava com 300 á 400 alunos.

A escola contava com o vigia Benedito Faria Mendes, em 1980. Ele permaneceu na escola ate o dia 30 de março de 2013. Após sua aposentadoria afirmou para a equipe que vive sua vida tranquilamente, sem as preocupações da escola.

Em agosto de 2000, foi inaugurada, na administração de Maria Pereira Alves Costa, a construção da Escola Estadual Princesa Izabel, no distrito de Santa Terezinha, com oito salas de aulas e três banheiro, cozinha, área administrativa e sala para os professores, direção, coordenação, secretaria, almoxarifado, sala de informática, sala de recurso multifuncional, quadra de esportes, dando continuidade do $1^{\circ}$ ao $9^{\circ}$ ano do ensino fundamental e EJA. No ano de 2003, na administração do diretor Charles Toni Dallacort, foi implantado o ensino médio no período noturno, permancendo este período até os dias atuais.

Em 2005, assume a direção da escola a professora Rosenir Salete Endres, dando continuidade aos trabalhos da Estadual Princesa Izabel, buscando melhorar o ensino e a aprendizagem, melhorando a estrutura física e implementando os recursos tecnológicos na escola.

A escola também possui ar condicionado em todas as salas materiais, mobília, pintura etc. No ano de 2010, a Escola Princesa Izabel, passou a ser designada "Escola do Campo" sendo regida por legislação específica do campo.

Agora em 2013 a escola continua no caminho para que possa seguir sempre rumo às mudanças.

Os alunos da escola, em uma pesquisa, informaram que a mesma continua um exemplo tanto no ensino, como na aprendizagem. Porém, acrescentaram que a escola em questão precisa de melhorias relacionadas ao esporte, lazer e uma biblioteca mais completa, com um espaço próprio para leitura. Além disso, ela necessita de experiências mais aprofundadas no campo.

Uma conquista bastante recente alcançada pela Escola Estadual Princesa Izabel foi o fato da escola ter sido campeã dos Jogos da Pátria 2013 em Itaporã, algo que encheu de orgulho todos os alunos e funcionários da escola.

\section{Transcrição do texto da Figura 11}

Assim como no texto sobre os doces, neste as imagens também completam o sentido do texto (diferentemente da apresentação pessoal que apresentam informação nova/diferente). Naquele, as fotos mostram as embalagens dos produtos, certificando o caráter industrial da fabricação dos doces de um grupo do grupo de mulheres de Itaporã. Neste, as imagens mostram aspectos da escola não verbalizados: a fachada, seus funcionários, e duas cenas de três adolescentes no ambiente escolar, reunidos descontraidamente, o que revela caráter familiar do ambiente escolar, não mencionado no tex to escrito. 
Na parte dos comentários, estes se alteram entre aqueles que se referem à reportagem, e aqueles que se referem à sua construção:

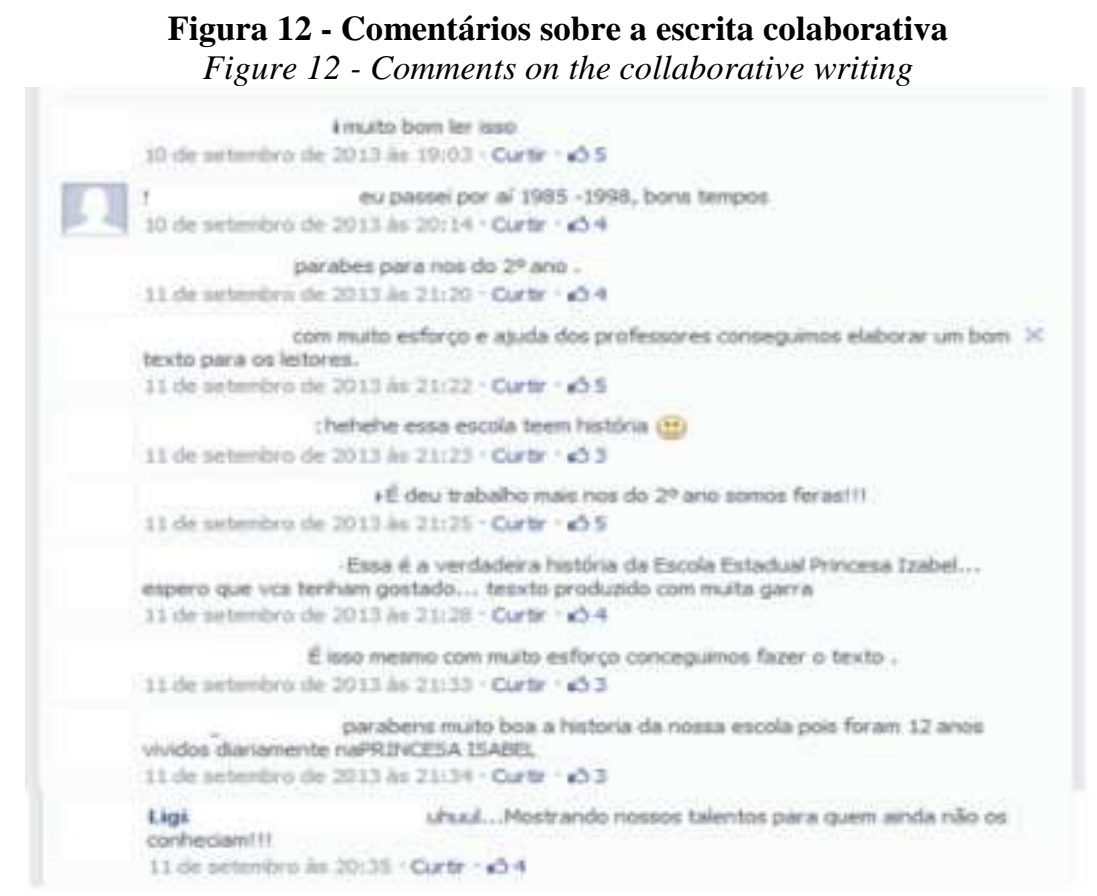

Alguns comentários feitos a partir da postagem sobre a escola também certificam esse caráter familiar, que passa pela relação entre os alunos atuais e outros alunos mais antigos e a escola: muito bom ler isso; parabéns muito boa a história da nossa escola pois foram 12 anos vividos diariamente na Princesa Isabel.

Os textos postados no Facebook são resultados de duas reescritas, realizadas com a orientação da professora oficial, que acompanhava o trabalho. A escrita colaborativa, pelo assunto e por ter sido realizada em conjunto, é o texto mais extenso da coletânea, o que explicaria o fato de apresentar mais inadequações em relação aos demais. É possível observar muitas falhas em relação à microestrutura e ortografia, à escrita padrão, e em relação à macroestrutura, à construção dos sentidos. Em relação à microestrutura, por exemplo, há uso de crase e de segmentação indevida de palavras (á, anoite, podesse), regência (um terreno, $\underline{o}$ qual futuramente será construído a nova escola), repetição excessiva da palavra escola no último parágrafo.

Em relação à macroestrutura, há, por exemplo, problemas de coerência (há referência à construção da antiga escola, que é retomada como nova); no $8^{\circ}$ parágrafo fala-se do vigia Benedito, sem que isso tenha qualquer relação com o que veio antes ou depois (o que pode ser 
justificado pelo fato de muitas pessoas terem participado da redação); há falta de informações importantes para a continuidade do texto - no penúltimo parágrafo, não está claro a qual pesquisa é feita referência. Outro exemplo relaciona-se a questões ideológicas e discursivas, para as quais se perdeu a chance de reflexão a partir do exercício da reescrita. É quando se fala, no quinto parágrafo, que o prefeito e sua esposa estiveram presentes na inauguração do novo prédio que abrigaria a escola. Poderia ter-se questionado, visando a uma terceira versão: Qual a relevância disso? Por que o destaque para o casal? Quem mais estava presente? A comunidade? Os futuros alunos? Havia autoridades de outros lugares? E, também: Para quem e com que interesse os alunos estão escrevendo o texto? A reelaboração não estaria apenas a serviço simplesmente de uma adequação, mas, sobretudo, da possibilidade de rever posicionamentos e de desenvolver uma postura mais crítica diante de fatos do cotidiano. Quando assume tal função, a correção possivelmente não pode ser limitada apenas a produção de uma ou duas reescritas.

Talvez como, na "cultura escolar", os textos sejam tomados apenas como tarefas escolares, limitados à circulação entre professor e, raramente, compartilhados com colegas de sala, a professora não tenha dado tanta atenção aos problemas - pois, nessa situação escolar, cumprem a "função" de compor o JV. Nesse caso, e somado a isso o fato de ter prazo para cumprir com o cronograma de atividades planejadas, a relevância de o texto ser exposto à página de acesso público não foi suficiente para esse maior cuidado. Outra possibilidade é que a comunidade, incluindo a professora, estivesse tão envolvida no fazer discursivo, que negligenciou a necessidade da terceira reelaboração. A aluna Ligiane revela a "delícia" desse fazer, evidenciando a importância de se situarem na sociedade como sujeitos-autores: uhuul... Mostrando nossos talentos para quem ainda não os conheciam!!!

É como se, na comunidade - alunos, seus familiares, educadores gestores, professora, professor-pesquisador, entre outros de Santa Terezinha -, a beleza da materialidade do trabalho na página virtual se sobrepusesse à própria construção dos sentidos e também a um rigor maior dos aspectos formais do texto.

Embora tenhamos fortes indícios desse foco que tomaram todos na realização de todas as etapas da atividade, é possível também perceber que não deve ter sido simples para os alunos ter passado da primeira para a segunda versão, no caso da escrita colaborativa. Rafaele, por exemplo, além de remeter à história da escola, deixa no seu comentário as marcas que caracterizam a atividade de escrever como um trabalho que exige dedicação, construção 
árdua: Essa é a verdadeira história da Escola Estadual Princesa Isabel...; Espero que vcs tenham gostado...tesxto produzido com muita garra. Sua colega, Katia, confirma em seguida: É isso mesmo com muito esforço conseguimos fazer o texto.

Como vemos, a atuação social pela escrita tomou um lugar não comum na tradição escolar. O comentário de Ligiane, destacado anteriormente (uhuul... Mostrando nossos talentos para quem ainda não os conheciam!!!), evidencia principalmente o fato não comum de os alunos saírem do lugar que os delimita como simples estudantes e ocuparem o lugar de autores efetivos, pois o que escrevem extrapola os muros da escola e toda a comunidade tem acesso. A escrita, estimulada por um projeto escolar, desempenha sua função social. E mais que isso, por se tratarem de alunos de uma área rural, o jornal foi uma conquista da visibilidade, em que os alunos puderam ir para o mundo literalmente, pois os textos e imagens por eles postados podiam ser vistos e lidos por todas as pessoas que acessassem a página do jornal virtual.

Os alunos noticiaram os mais diversos assuntos referentes ao distrito rural em que vivem: entrevista com vereadores; história do distrito; reportagem sobre a fábrica de doces de goiaba do distrito; informações sobre projetos municipais; estaduais e federais na região; festas e atrativos da comunidade; classificados; dentre outros. Envolver os alunos na produção de um jornal virtual, com leitores reais (e não somente o professor) foi uma forma de tornar a atividade significativa e a produção dinâmica, pois é possível que não se tenha tanto entusiasmo quando o que se faz não vai além de uma simples atividade escolar, para um leitor apenas (quando ainda o professor lê!).

Os exemplos mostram sobreposições e complementariedades entre eventos e práticas de diferentes tipos. As notícias/reportagens que os alunos veicularam no Facebook não têm nada de novo para a comunidade - são gêneros discursivos reconhecidos socialmente independentemente do suporte em que estão. O modo como foram construídas e embora postadas no meio digital, seguem a tradição escolar. No caso da escrita em grupo (que se pretendia colaborativa), a gênese do texto é um misto de modos grafocêntrico e digital, como mostrarmos.

A novidade está, para os alunos, na facilidade de incluir as imagens, no compartilhamento e na possibilidade de emitir comentários e de ter o seu texto comentado e visto por outras pessoas que não fazem parte estritamente do ambiente escolar. Para a comunidade, a novidade está no fato de o JV ter sido produzido por aprendizes de escrita 
familiares a eles e pela oportunidade de visualizarem suas potencialidades, como também revelou o comentário de Lígia.

Os dados nos mostram que, ao contrário daquilo que têm suposto muitos educadores, não há uma fronteira rígida entre as práticas de escrita da cultura grafocêntrica e aquelas da cultura digital. A habilidade de escrever uma notícia, por exemplo, veio com o surgimento do jornal impresso já em 1447 com o alemão Johann Gutenberg e, dessa habilidade, entre outras, sobrevivem os jornais digitais aos quais os alunos têm acesso. Ou seja, a escrita em si e a mediação tecnológica, seja da tradicional escrita grafocêntrica ou da tecnologia digital, não é fato novo na nossa cultura. Nesse sentido, Signorini (2012) fala em "bordas" e não delimitações rígidas entre a escrita veiculada no suporte impresso e aquela veiculada no suporte computacional.

\section{PALAVRAS FINAIS PARA INÍCIO DE CONVERSA}

O projeto desenvolvido contribuiu para aproximar uma prática envolvendo a escrita familiar aos alunos de práticas de escritas escolares. Trazer para a sala uma prática dos alunos (postar e comentar no Facebook) proporcionou um clima favorável para a escrita da apresentação pessoal e das notícias/reportagens). Para produzir os textos, os alunos trabalharam em sala de aula várias manchetes, motivadas sempre por discussões sobre aquilo que estava acontecendo na região ou, até mesmo, de algo que já havia acontecido e que continuava marcante para a comunidade que ali vive. Assim, o trabalho nos mostra que partir de algo familiar aos alunos para depois chegar a algo que eles devem/precisam desenvolver pode ser bem produtivo para os professores, além de quebrar o abismo entre as práticas escolares e as extraescolares e proporcionar o diálogo entre docente e discente.

Nessa tentativa de quebra, que representou esse projeto escolar, e focalizando as ações docentes na condução do trabalho, podemos perceber um misto entre modos de conduzir tarefas escolares e modos de conduzir a escrita de textos para o JV, os quais não deixam se ser escolares também. Além disso, a forma de conduzir uma escrita "colaborativa", nunca antes experimentada naquele contexto (nem pelos alunos, nem pelo professor), é uma novidade, para a qual é preciso um encaminhamento diferente daquele realizado. Se, para um caso, duas versões foram suficientes para se "autorizar" a publicação, no outro caso, vemos a necessidade de ter ocorrido pelo menos mais uma. Além disso, é preciso pensar em um modo 
de condução no qual de fato os estudantes ajam colaborativamente de fato. Para perceber isso, contudo, é necessário passar pela experiência.

Mais fácil do que arriscar-se é manter uma perspectiva dicotômica entre os nativos digitais, como são considerados os alunos aqui retratados, e os migrantes digitais, como considerados os professores. Mas essa comodidade não contribui para quem deve ensinar e para quem deve aprender. Como vemos, não há fronteiras rígidas entre a cultura grafocêntrica e a cultura da tecnologia digital. Assim, parece não fazer sentido a proibição do uso do Facebook no ambiente escolar, uma vez que, utilizado de forma adequada e bem planejada, ele pode funcionar como uma ferramenta que ajuda a estimular os alunos a escreverem, à medida que traz à tona situações interativas, e, assim, propicia construções de si próprios, significações, que os alunos não fariam somente diante do papel.

Nada pode justificar a agressão física sofrida pela professora que proibiu seus alunos de usarem o Facebook em aula, caso mencionado na introdução deste artigo, consequência de uma parcela da sociedade que perdeu seus valores éticos e morais. Contudo, essa situação também exterioriza o sufoco dos alunos que não veem mais sentido nas práticas escolares. Essa triste situação nos leva a algumas reflexões para as mudanças urgentes que devem sofrer o sistema educacional. Pensar que o limite entre as práticas de uma geração e de outra não se dá por fronteiras, mas por bordas, pode ajudar a construção de um ambiente de ensino mais interessante. Uma geração precisa da outra e as anteriores sempre terão algo importante a passar aos posteriores. Nenhuma prática de escrita surge desvinculada das anteriores. Assim, os nativos digitais não serão proficientes nesse meio se se situarem simplesmente como consumidores passivos do que lhes é dado nas telas. E os migrantes digitais também não o serão, caso se coloquem numa posição reativa diante das novas tecnologias.

A nova geração, os adolescentes nativos digitais, precisa desenvolver as habilidades de escrita (que independem do suporte) para agir criticamente, como cidadãos, no mundo em que (fora da escola) traz tudo pela tela do computador. Concordamos com Signorini (2012, p. 283) que "o grande desafio que se coloca hoje para professores e para formadores de professores é o da ação crítica". Assim, produzir textos relevantes socialmente no Facebook pode representar um primeiro passo para outras ações, criações, produções que ajudam nossos alunos a serem mais produtores do que consumidores, seguindo a corrente inversa para a qual o capitalismo impulsiona. Além disso, os alunos necessitam aprender a fazer crítica de forma ética, quando a fizerem nas redes sociais. Para isso, também é necessário que o professor, 
diferentemente do que ocorreu na experiência mostrada neste artigo, conduza a reescrita a partir de questionamentos em relação aos acontecimentos narrados/descritos/contados e não apenas visando à adequação ao que ele elege ou enxerga como prioritário em relação à norma padrão.

Diante de um fato similar ao relatado no início do artigo, Signorini (2012), fala de um blog que alunos de uma escola pública de Campinas-SP produziram rechaçando e expondo negativamente seus professores. A escola que, por fim, "abafou" o caso. Algumas pessoas que ouviram o relato de uma professora que acompanhou o episódio ficaram indignadas diante do fato da escola perder

a oportunidade de inteirar-se do que os alunos poderiam fazer com a hipermídia quanto de ensinar-lhes a fazer crítica de forma ética, a explorar melhor e expandir os recursos de linguagem utilizados, a selecionar e avaliar com critérios mais claros as redes de circulação dos conteúdo exibidos, a fazê-los compreender melhor os significados e as implicações do que estavam produzindo, entre tantas outras coisa (p. 294).

Esse caso e o outro, aqui relatado, têm em comum, além de envolverem a tecnologia digital, o fato de os professores terem sido, em um caso, moral e no outro, fisicamente prejudicados. Somado a isso, o descomprometimento e o desinteresse dos alunos em relação à instituição escolar consequentes do próprio fato de a escola não os estar munindo das habilidades de que necessitam para atuarem em benefício da sociedade.

Considerar outras práticas de letramento para propiciar recursos aos alunos contribui para uma maior valoração dessas práticas e, portanto, da atuação social deles. Tudo isso demonstra que o desenvolvimento de trabalhos educativos por meio de ferramentas digitais, inclusive aquelas que são rechaçadas rotineiramente por grande parte dos professores, pode ajudar a munir positivamente nossos alunos, como nos mostrou o desenvolvimento do jornal virtual na turma do $2^{\circ}$ ano do Ensino Médio. Longe de serem perturbadoras da ordem escolar, redes sociais e outros ambientes virtuais podem funcionar como verdadeiros colaboradores dos agentes institucionais.

\section{REFERÊNCIAS}

AMYUNI, S. Professora barra acesso ao facebook e leva vassourada em sala de aula. G1São Carlos e Araraquara, 26 ago. 2013. Disponível em <1.globo.com/sp/sao-carlosregiao/noticia/2013/08/professora-barra-acesso-facebook-e-leva-vassourada-em-sala-de-aulapirassununga.html>. Acesso em: 26 set. 2014.

BAKHTIN, M.. Marxismo e filosofia da linguagem. São Paulo: Hucitec; $6^{\text {a }}$ ed. [1992 (1929)]. 
BUIN-BARBOSA, E. Mixagem de práticas de escrita na escola. In: Gonçalves, A.V. \& BAZARIM, M. Interação, gêneros e letramento: a reescrita em foco.Campinas, SP: Pontes Editores, 2013.

CORRÊA, M. L. G. Letramento e heterogeneidade da escrita no ensino de Português. In Signorini, Inês. (org.). Investigando a relação oral/escrito e as teorias do letramento. Campinas: Mercado de Letras, 2001.

CORRÊA, Manoel Luiz Gonçalves. O modo heterogêneo de constituição da escrita. São Paulo: Martins Fontes, 2004.

CORRÊA, Manoel Luiz Gonçalves. Pressupostos teóricos para o ensino da escrita: entre a adequação e o acontecimento. UFMG, 2007.

MARQUES, F. Curtir e compartilhar: uma nova onda de ferramentas digitais causa impacto no modo de trabalhar dos pesquisadores. In Revista FAPESP, ed. 195, maio de 2012. Disponível em <http://revistapesquisa.fapesp.br/2012/05/11/curtir-e-compartilhar/>. Acesso em: 26 set. 2014.

PINHEIRO, P. Novas práticas colaborativas de escrita por meio de ferramentas da internet. Em Signorini, Inês \& Fiad, Raquel (org.) Ensino de língua: das reformas, das inquietações e dos desafios. Belo Horizonte: Editora UFMG, 2012. P. 248-81.

PRENSKY, M.: Digital Natives Digital Immigrants. In: PRENSKY, Marc. On the Horizon. NCB University Press, Vol. 9 No. 5, October (2001a). Disponível em $<$ http://www.marcprensky.com/writing/>. Acesso em 02/Abril/2014.

REFERENCIAL CURRICULAR DO ENSINO MÉDIO - SED / MS, 2007.

RUIZ, E. Como se corrige redação na escola. Campinas, SP: Mercado de Letras, 2003.

SIGNORINI, I. Letramento e inovação no ensino e na formação do professor de Língua Portuguesa. In: SIGNORINI, I. (org.). Significados da inovação no ensino de Língua Portuguesa e na formação de professores. Campinas: Mercado de Letras, 2007. p. 211-228.

SIGNORINI, I. \& FIAD, R. S. (org.) Ensino de língua: das reformas, das inquietações e dos desafios. Belo Horizonte: Editora UFMG, 2012. P. 03-303.

\section{Paulo César Gonçalves}

Mestre em Letras pela Universidade Federal da Grande Dourados - UFGD (2013-2015). Especialista em Mídias Educacionais (UFMS). Especialista em Linguística (UFGD). Graduação em Letras, com habilitação em Português/Espanhol e respectivas literaturas (UEMS). Professor efetivo da Rede Estadual de Ensino de Mato Grosso do Sul.

E-mail: pcerudito@gmail.com

Endereço: Universidade Federal da Grande Dourados - UFGD R. João Rosa Góes, 1761 Vila Progresso, Dourados - MS, 79825-070

\section{Edilaine Buin}

É professora adjunta da Universidade Federal da Grande Dourados (UFGD), onde atua na graduação e no Programa de Pós Graduação em Linguística. É pós-doutora pela Universidade de São Paulo (USP)/Departamento de Letras Clássicas e Vernáculas (FFLCH); doutora e Mestre em Linguística pela Universidade Estadual de Campinas (UNICAMP), nas áreas de Linguística Textual e de Aquisição da Escrita, respectivamente. É graduada em Letras, licenciatura e bacharelado, pela mesma universidade.

E-mail: edilainebuin@gmail.com

Endereço: Universidade Federal da Grande Dourados - UFGD R. João Rosa Góes, 1761 Vila Progresso, Dourados - MS, 79825-070 